\title{
Serum lactate poorly predicts central venous oxygen saturation in critically ill patients: a retrospective cohort study
}

\author{
Roshan Bisarya ${ }^{1}$, Deena Shaath ${ }^{1}$, Arman Pirzad ${ }^{2}$, Lewis Satterwhite ${ }^{3}$, Jianghua He ${ }^{4}$ and Steven Q. Simpson ${ }^{3^{*}}$ (D)
}

\begin{abstract}
Background: Serum lactate and central venous oxygen saturation $\left(\mathrm{S}_{\mathrm{CV}} \mathrm{O}_{2}\right)$ are commonly used and commonly recommended as markers of tissue oxygenation in shock states. Medical literature has both explicitly stated and implied that the two biomarkers are interchangeable in the management of patients with shock. However, there have been relatively few direct comparisons of these tests in clinical circumstances, and the relationship between them is uncertain. The objective of our study was to evaluate whether simultaneous or near-simultaneous measurements of lactate and $\mathrm{ScvO}_{2}$ reveal a consistent relationship between these two biomarkers.

Methods: A retrospective cohort study was conducted in an urban, academic US hospital. All adults in ICUs between March 2007 and March 2017 who had a lactate measurement and $\mathrm{ScvO}_{2}$ or mixed venous oxygen saturation $\left(\mathrm{SvO}_{2}\right)$ measurement made $+/-1 \mathrm{~h}$ from the lactate were included. Linear and non-linear correlations of $\mathrm{ScvO}_{2}$ and lactate were assessed in a variety of shock states.

Results: Two thousand sixty-two patients were included. Lactate and $\mathrm{ScvO}_{2}$ correlated poorly $\left(r^{2}=0.0041\right.$, $p=0.0019)$. This was true for patients with $\mathrm{ScvO}_{2} \leq 65 \%\left(r^{2}=0.0431, p<0.001\right)$, patients with normal kidney and liver function $\left(r^{2}=0.0517, p<0.001\right)$, and septic shock patients $\left(r^{2}=0.0037, p=0.17\right)$. For patients with an $\mathrm{O}_{2}$ extraction ratio $\geq 50 \%$, lactate and $\mathrm{ScvO}_{2}$ were strongly correlated $\left(r^{2}=0.93, p=0.0019\right)$, but these patients represented only $2.8 \%$ of patients in whom the ratio could be calculated.

Conclusions: Lactate can predict $\mathrm{ScvO}_{2}$ when patients are at or below the critical oxygen delivery threshold, but relatively few shock patients meet this criterion. In the overall population of critically ill patients, serum lactate predicts $\mathrm{S}_{\mathrm{cvO}}$ 2 poorly, even after controlling for factors that may affect lactate production. Lactate and $\mathrm{ScvO}_{2}$ should not be assumed to be interchangeable markers of tissue oxygenation/perfusion.
\end{abstract}

Keywords: Lactic acid, Shock, Hyperlactatemia, Hypoxia, Sepsis, Septic shock

\section{Background}

The critical care literature has considered central venous oxygen saturation $\left(\mathrm{ScvO}_{2}\right)$, mixed venous oxygen saturation $\left(\mathrm{SvO}_{2}\right)$, and serum lactate to be measures of tissue oxygenation in shock [1-9]. Following the Rivers trial of early goal-directed therapy (EGDT) for sepsis, $\mathrm{ScvO}_{2}$ became popular as a substitute for $\mathrm{SvO}_{2}$ in a variety of shock states [10], and the two measures have been

\footnotetext{
*Correspondence: ssimpson3@kumc.edu

${ }^{3}$ Division of Pulmonary and Critical Care Medicine, University of Kansas, 3901

Rainbow Boulevard, Mail Stop 3047, Kansas City, KS 66160, USA

Full list of author information is available at the end of the article
}

demonstrated to be strongly correlated $[6,8,11,12]$. A trio of controlled trials subsequently demonstrated that EGDT does not provide a survival advantage in all patients with septic shock, but the studies did not address the utility of $\mathrm{ScvO}_{2}$ as a target for resuscitation of septic shock, because half of the patients in these trials had normal $\mathrm{ScrO}_{2}$ at the time of randomization [13]. Some authors advocate that $\mathrm{ScrO}_{2}$ remains a vital component of sepsis treatment that should not be left out [14]. Serum lactate has also been used as a marker for tissue oxygenation $[1-3,5,9,15,16]$; in fact, both $\mathrm{ScvO}_{2}$ and lactate are independent predictors of mortality in sepsis,

(C) The Author(s). 2019 Open Access This article is distributed under the terms of the Creative Commons Attribution 4.0 International License (http://creativecommons.org/licenses/by/4.0/), which permits unrestricted use, distribution, and 
and normalization of either or both biomarkers is associated with improved outcomes in sepsis and septic shock [17-23]. Additionally, both lactate and $\mathrm{ScvO}_{2}$ have been used as markers of tissue oxygenation in cardiogenic and hemorrhagic shocks [24-28].

Given their use as markers of tissue oxygenation, it has been posited that levels of serum lactate and $\mathrm{ScvO}_{2}$ may be inversely correlated in at least some forms of shock, as $\mathrm{ScvO}_{2}$ should be decreased in patients with inadequate tissue perfusion, and inadequate tissue perfusion should result in increased lactate production [8]. It is likely that such an inverse relationship exists below the critical oxygen delivery point in any given patient, but the relationship could be more complex at other levels of oxygen delivery and uptake. In fact, Astiz et al. were unable to determine a level of oxygen delivery or of $\mathrm{SvO}_{2}$ that is predictably associated with lactic acidosis in patients with sepsis or acute myocardial infarction [29]. Furthermore, lactate production can be stimulated by alternate mechanisms, and serum lactate can be increased in the absence of tissue hypoxia. We evaluated a large number of patients with shock of various etiologies to examine the relationship between serum lactate and $\mathrm{ScvO}_{2}$ and to determine whether a correlation does exist between levels of these two markers in any shock subset.

\section{Methods}

This was a retrospective cohort study performed at The University of Kansas Hospital (TUKH) in Kansas City, Kansas, in accordance with STROBE guidelines for observational studies. The protocol was approved by the Institutional Review Board, with approval number 00001581. All data were obtained from the electronic medical record (Epic, Verona, WI, USA) and collected in Crystal Reports (SAP Software Solutions). All adults ( $\geq 18$ years) in ICUs between March 2007 and March 2017 who had a lactate measurement and measurement of central venous or mixed venous blood gases made $\pm 1 \mathrm{~h}$ from the lactate were included in the study. Previous to August 2014, there was no specific laboratory category in the electronic medical record (EMR) for $\mathrm{ScvO}_{2}$, and these measurements were reported by the laboratory as $\mathrm{SvO}_{2}$. After August 2014, $15.4 \%$ of venous gases were $\mathrm{SvO}_{2}$ measures. We assumed similar proportions for gases measured before the $\mathrm{ScvO}_{2}$ category became available for reporting, and we combined $\mathrm{ScvO}_{2}$ and $\mathrm{SvO}_{2}$ measures for analyses but refer to the values as $\mathrm{ScvO}_{2}$. For both time periods, we excluded any blood gases characterized only as "venous."

We recorded age, sex, hospital mortality, length of hospital stay (LOS), length of ICU stay (ICU-LOS), need for dialysis, and need for mechanical ventilation. Discharge diagnoses regarding the type of shock state were recorded based on the International Classification of Diseases ICD-9 or ICD-10 codes and included septic, cardiogenic, traumatic, and shock not otherwise specified (NOS).

The following data were collected within \pm 1 day of the patient selection data: creatinine, total bilirubin, aspartate aminotransferase (AST), alanine aminotransferase (ALT), total bilirubin, hemoglobin, and thiamine. We recorded the following medication use in ICU: metformin, epinephrine, norepinephrine, dopamine, and linezolid, which we refer to collectively as lactic acidosis-associated medications. Additionally, using ICD-9 and ICD-10 codes, we determined if the patients had the following pre-existing conditions: chronic kidney disease (CKD), chronic respiratory failure (CRF), chronic liver disease (CLD), chronic hypertension, and type 2 diabetes.

Statistical analysis was performed using Stata version 15.0 (StataCorp, College Station, TX, USA). Simple least squares linear regressions were performed, comparing serum lactate concentration with $\mathrm{ScvO}_{2}$ for all eligible patients. We performed secondary regression analyses of lactate and $\mathrm{ScvO}_{2}$ for patients meeting the following specific constraints: normal hepatic and renal function (AST $\leq 40 \mathrm{U} / \mathrm{L}$ or $\mathrm{ALT} \leq 50 \mathrm{U} / \mathrm{L}$ and creatinine $\leq 1.2$ $\mathrm{mg} / \mathrm{dL})$, septic shock, low $\mathrm{ScvO}_{2}(\leq 65 \%)$, increased lactate $(>2 \mathrm{mmol} / \mathrm{L}$ ), anemia (hemoglobin $\leq 7.0 \mathrm{~g} / \mathrm{dL}$ ), state of lower adrenal activation (cortisol $\leq 25 \mu \mathrm{g} / \mathrm{dL}$ ), cardiogenic shock, absent history of CKD or CLD, in-hospital mortality, and simultaneous measurements of $\mathrm{ScrO}_{2}$ and lactate. We completed regression analyses of lactate and $\mathrm{ScvO}_{2}$ for patients who were and who were not receiving the lactic acidosis-associated medications. In patients with an $\mathrm{SaO}_{2}$ measurement, we also completed a regression analysis of lactate and $\mathrm{ScvO}_{2}$ for those who had passed the critical oxygen delivery threshold (oxygen extraction ratio $\geq 50 \%$ ). We performed additional regression analyses for lactate with factors that could affect lactate levels: cortisol, AST, ALT, total bilirubin, and creatinine. To observe intra-patient correlations between lactate and $\mathrm{ScvO}_{2}$, we used a simple linear regression of change in lactate with change in $\mathrm{ScvO}_{2}$ for patients with multiple measurements over the course of a single ICU stay. Additionally, we plotted lactate levels vs sextiles of $\mathrm{ScvO}_{2}$ and completed a restricted cubic spline analysis of lactate and $\mathrm{ScvO}_{2}$ to further describe their relationship. We also performed independent samples $t$ tests examining mean lactate levels in patients with CKD and CLD. We also performed multiple linear regression modeling with lactate as the outcome variable and AST, creatinine, $\mathrm{ScvO}_{2}$, cortisol, total bilirubin, and the medications of epinephrine, norepinephrine, and linezolid as predictor variables. To determine the contribution to the model of each variable, we calculated the change in $r^{2}$ when individual variables were added. 


\section{Results}

During the period of study, a total of 255,311 patients were admitted to the hospital, of which 53,745 patients were admitted to ICUs and 2062 patients were eligible for study, totaling 2348 paired lactate and $\mathrm{ScvO}_{2}$ measures (Fig. 1). Demographics and clinical features of the included patients are shown in Table 1. Five hundred seventy-one patients were given an ICD-9 or ICD-10 shock diagnosis, most of them having septic shock (73\%). The median serum lactate for the entire cohort was $1.9 \mathrm{mmol} /$ L (IQR 1.3-3.3), and the median $\mathrm{ScvO}_{2}$ was $73.5 \%$ (IQR 64.5-81.8). There were 1103 increased lactates $(>2 \mathrm{mmol} /$ $\mathrm{L}$ ), and 607 decreased $\mathrm{ScvO}_{2}$ measures $(<65 \%)$. The likelihood of $\mathrm{ScvO} 2<65 \%$ was increased in patients with serum lactate $>2 \mathrm{mmol} / \mathrm{L}(\mathrm{OR}=1.69,95 \% \mathrm{CI}=1.40$ 2.05, $p=0.0000$ ) (Additional file 1).

The simple linear regression data are shown in Additional file 2. We also performed log transformations

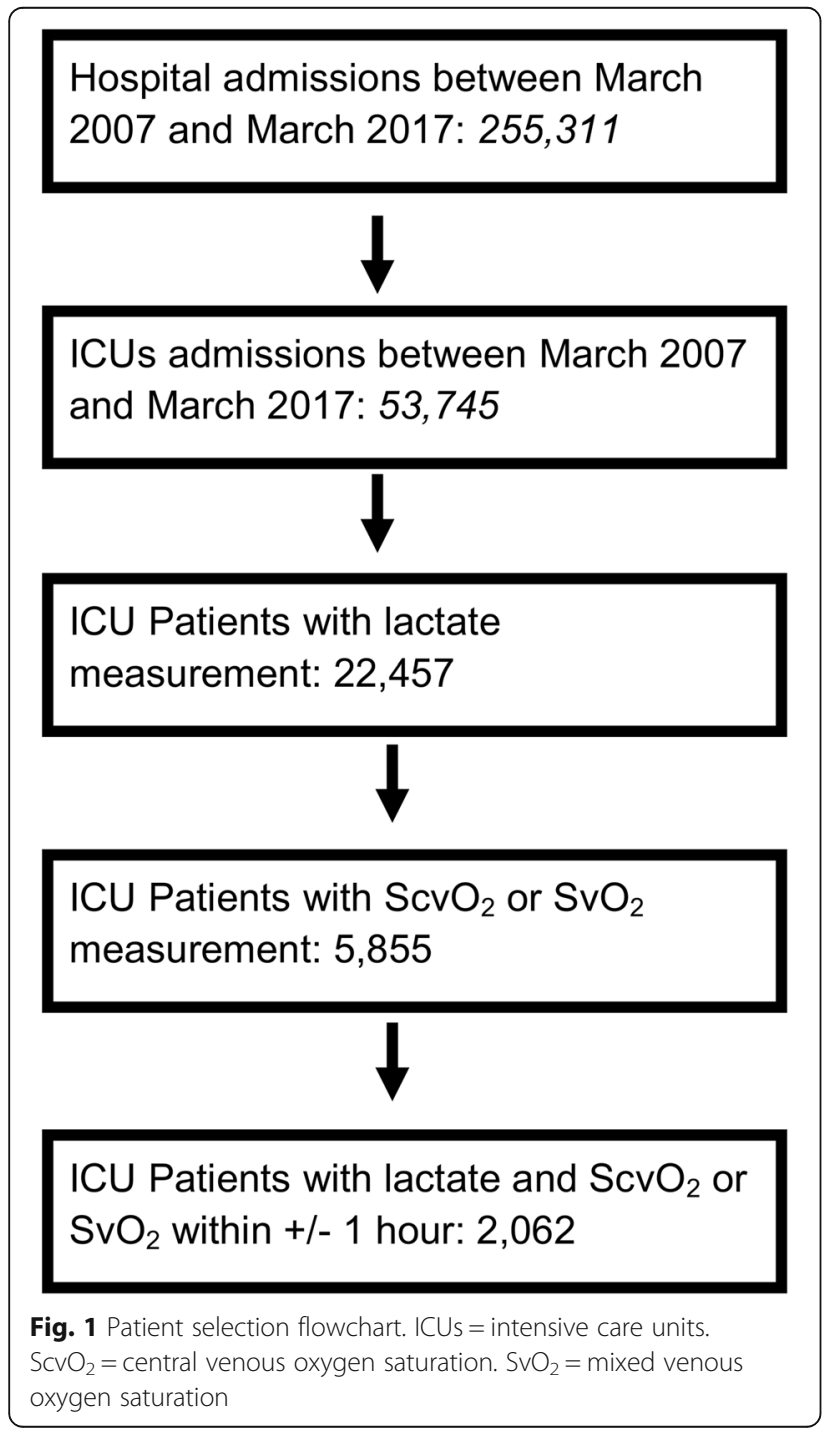

Table 1 Patient demographics and clinical values

\begin{tabular}{|c|c|}
\hline Patient characteristics & Value \\
\hline Mean age, years (SD) & $58(19)$ \\
\hline Males (\%) & $1113(54)$ \\
\hline Mortality (\%) & $1134(55)$ \\
\hline Mean hospital length of stay (SD) & $20(22)$ \\
\hline Mean ICU length of stay (SD) & $8.8(13)$ \\
\hline Need for dialysis (\%) & $309(15)$ \\
\hline Mechanically ventilated (\%) & $1258(61)$ \\
\hline Sepsis (\%) & $80(3.9)$ \\
\hline Severe sepsis (\%) & $1051(51)$ \\
\hline Septic shock (\%) & $454(22)$ \\
\hline Cardiogenic shock (\%) & $68(3.3)$ \\
\hline Traumatic shock (\%) & $49(2.4)$ \\
\hline Shock NOS (\%) & $43(2.1)$ \\
\hline Diabetes (\%) & $763(37)$ \\
\hline Chronic kidney disease (\%) & $701(34)$ \\
\hline Chronic respiratory failure (\%) & $309(15)$ \\
\hline Chronic hypertension (\%) & $1340(65)$ \\
\hline Chronic liver disease (\%) & $639(31)$ \\
\hline Serum lactate < $2.0 \mathrm{mmol} / \mathrm{L}(\%)$ & $1186(51)$ \\
\hline Serum lactate $2.0-4.0 \mathrm{mmol} / \mathrm{L}$ & $732(31)$ \\
\hline Serum lactate > $4.0 \mathrm{mmol} / \mathrm{L}(\%)$ & $430(18)$ \\
\hline $\mathrm{ScvO}_{2}<65(\%)$ & $607(26)$ \\
\hline $\mathrm{ScvO}_{2}$ 65-75 (\%) & $673(29)$ \\
\hline $\mathrm{ScvO}_{2}>75(\%)$ & $1068(45)$ \\
\hline Patients receiving epinephrine (\%) & $206(10)$ \\
\hline Patients receiving norepinephrine (\%) & $1237(60)$ \\
\hline Patients receiving dopamine (\%) & $1835(89)$ \\
\hline Patients receiving metformin (\%) & $134(6.5)$ \\
\hline Patients receiving linezolid (\%) & $474(23)$ \\
\hline Cortisol mean (SD) in $\mu \mathrm{g} / \mathrm{dL}(n=603)$ & $37.3(33.8)$ \\
\hline Creatinine mean (SD) in mg/dL $(n=1377)$ & $1.87(1.72)$ \\
\hline AST mean (SD) in U/L $(n=1166)$ & $374(1455)$ \\
\hline Hemoglobin mean (SD) in $\mathrm{g} / \mathrm{dL}(n=1139)$ & $9.68(2.22)$ \\
\hline Thiamine mean (SD) in $\mu \mathrm{g} / \mathrm{dL}(n=8)$ & $154(68.2)$ \\
\hline Total bilirubin mean $(S D)$ in $\mathrm{mg} / \mathrm{dL}(n=1170)$ & $2.39(4.35)$ \\
\hline
\end{tabular}

$\mathrm{ICU}^{i}$ ntensive care unit, $\mathrm{SCVO}_{2}$ central venous oxygen saturation, AST aspartate aminotransferase

and exponential analyses, where appropriate, to determine goodness of fit of those models; outcomes displayed similarly weak correlations. Linear regression of lactate and $\mathrm{ScvO}_{2}$ showed a weak negative correlation between the two $\left(n=2348, r^{2}=0.0041, p=0.0019\right)$ (Fig. 2). We also evaluated lactate and $\mathrm{ScvO}_{2}$ simple linear regressions under different conditions. Lactate and $\mathrm{ScvO}_{2}$ were not correlated or weakly correlated in 


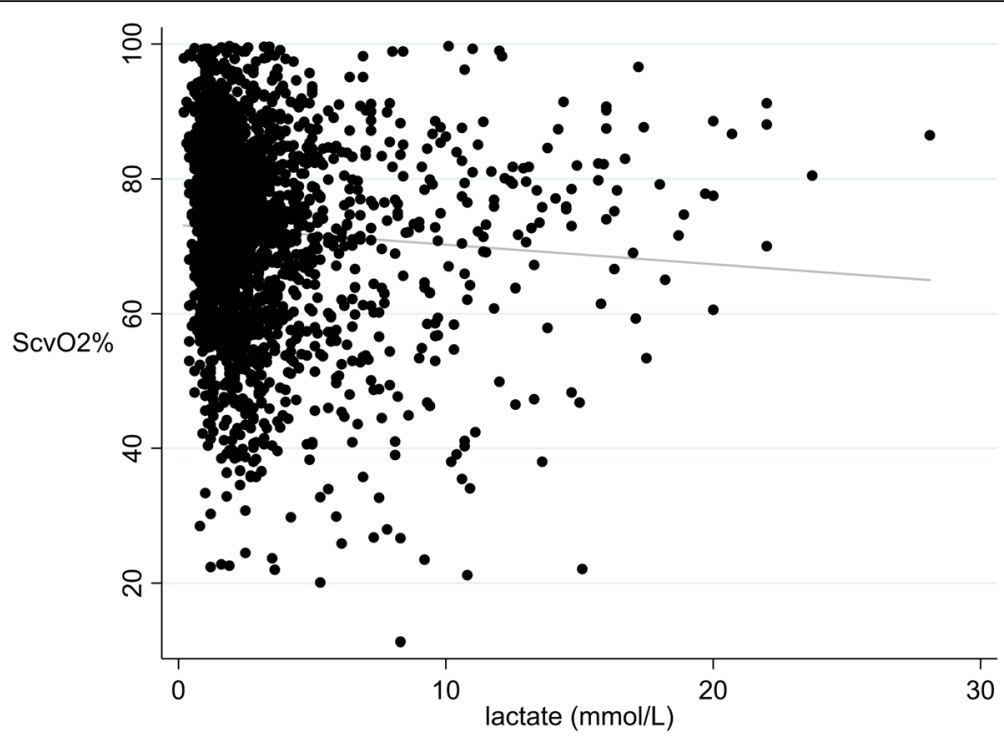

Fig. 2 Lactate and $\mathrm{ScvO}_{2}$ simple linear regression. $\mathrm{ScvO}_{2}=$ central venous oxygen saturation. A simple linear regression between lactate and $\mathrm{ScvO}_{2}$ was performed with all pairs of lactate and $\mathrm{ScvO}_{2}(n=2348)$ in the study. $r^{2}=0.0041$ and $p=0.0019$. The equation for the line of best fit was $\mathrm{ScVO}_{2}=73.2-0.29$ (lactate)

patients with presumed tissue hypoxia, as evidenced by lactate $>2 \mathrm{mmol} / \mathrm{L}\left(r^{2}=0.0003, p=0.59\right)$, high oxygen extraction, indicated by $\mathrm{ScrO}_{2} \leq 65 \%\left(r^{2}=0.0431\right.$, $p<0.001)$, and patients with anemia, indicated by hemoglobin $\leq 7.0 \mathrm{~g} / \mathrm{dL}\left(r^{2}=0.0062, p=0.41\right)$. To mitigate the effect of endogenous epinephrine as a stimulus for lactate production, we evaluated patients with cortisol $\leq 25 \mu \mathrm{g} / \mathrm{dL}$, as a marker of low adrenal activation, but lactate and $\mathrm{ScvO}_{2}$ remained poorly correlated $\left(r^{2}=0.0140, p=0.053\right)$. There was no correlation in patients who were not receiving the lactic acidosis-associated medications $\left(r^{2}=0.0317, p=0.25\right)$. However, lactate very strongly predicted $\mathrm{ScvO}_{2}$ in patients with an oxygen extraction ratio greater than $50 \%$ (Additional file $3, r^{2}=0.93, p=0.0019$ ), although only six patients of the 211 with both $\mathrm{SaO}_{2}$ and $\mathrm{ScvO}_{2}$ measurements had an oxygen extraction ratio of that magnitude. No type of shock predominated in these patients, and liver and kidney functions were intact in all of them. In the restricted cubic spline analysis of lactate and $\mathrm{ScvO}_{2}$ (Additional file 4), as well as the lactate vs $\mathrm{ScvO}_{2}$ sextile plot (Additional file 5), lactate showed a U-shaped relationship with $\mathrm{ScvO}_{2}$, with the highest lactate levels at the lowest and highest percentage values of $\mathrm{ScvO}_{2}$.

Because increased lactate is a significant feature of shock, we assessed lactate and $\mathrm{ScvO}_{2}$ regressions in patients with various types of shock. No correlation was found in patients with cardiogenic shock $\left(r^{2}=0.0064\right.$, $p=0.49)$ or septic shock $\left(r^{2}=0.0037, p=0.17\right)$ (Fig. 3). To examine whether the lack of correlation represented population variability in the relationship of lactate and
$\mathrm{ScvO}_{2}$, we evaluated intra-patient changes in the two variables among 286 patients who had multiple measurements over the course of an ICU stay; again, the relationship was weak $\left(r^{2}=0.0302, p<0.001\right)$, even when we only included patients with some degree of lactate clearance (Additional file $6, r^{2}=0.0137, p=0.19$ ). As described in Additional file 2, lactate and $\mathrm{ScvO}_{2}$ displayed weak correlations under conditions of no liver or kidney dysfunction, simultaneous measurement, and only $\mathrm{ScvO}_{2}$ values after March 2014. In our analyses with other factors that could affect lactate, it was poorly correlated with cortisol (Additional file 7), AST, ALT (Additional file 8), total bilirubin, creatinine, and the lactic acidosis-associated medications. Patients with CLD had a significantly higher mean lactate than patients without CLD, and there remained only very weak correlation of lactate and $\mathrm{ScvO}_{2}$; there was no significant difference in mean lactate when we compared patients with and without CKD (Additional file 9).

Because lactate was a poor predictor of $\mathrm{ScvO}_{2}$ in the majority of analyses, we used multiple linear regression modeling to evaluate parameters that may have affected serum lactate levels (Table 2). We evaluated combinations of predictor variables that were statistically correlated with lactate levels in univariate regressions: $\mathrm{ScvO}_{2}$, cortisol, creatinine, AST, ALT, total bilirubin, and the medications of epinephrine, norepinephrine, and linezolid. Table 2 shows the effect of any one of these variables in the model by showing the effect on $r^{2}$ of removing the indicated variable from the model. The most significant model had a coefficient of determination $\left(r^{2}\right)$ of $0.3667(p<0.001)$ and included all predictor variables. 


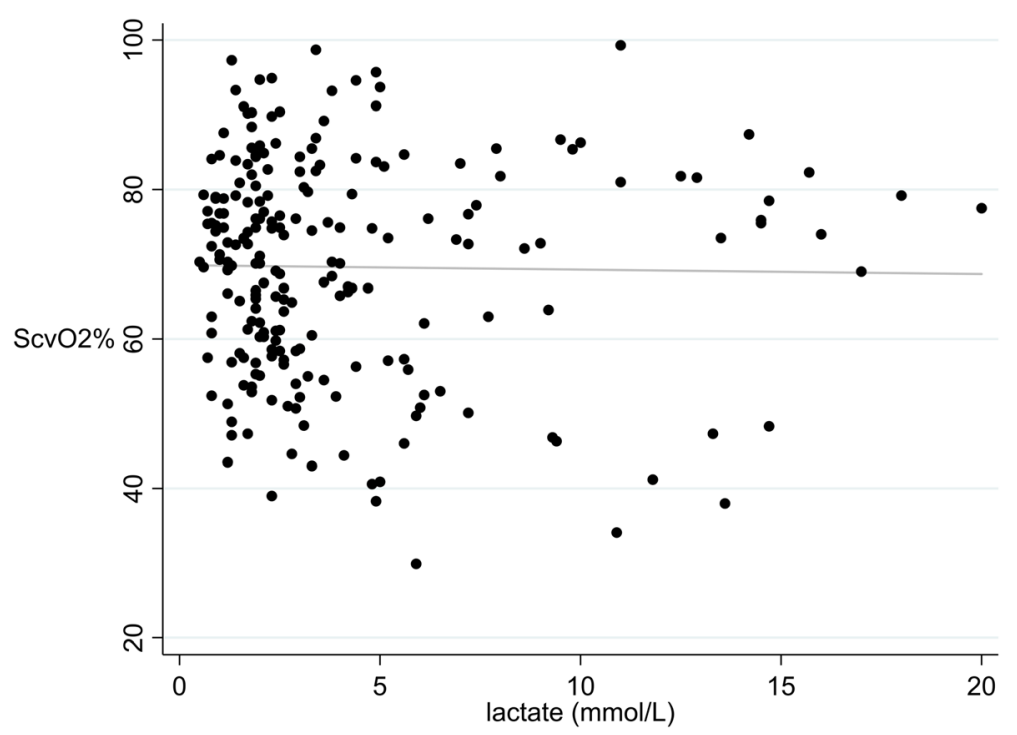

Fig. 3 Lactate and $\mathrm{ScvO}_{2}$ (only septic shock patients) simple linear regression. $\mathrm{ScvO}_{2}=$ central venous oxygen saturation. A simple linear regression was performed with the 508 paired measurements of lactate and $\mathrm{ScvO}_{2}$ in patients diagnosed with septic shock. $r^{2}=0.0037$ and $p=0.17$. The equation for the line of best fit was $\mathrm{ScvO}_{2}=72.7-0.26$ (lactate)

$\mathrm{ScrO}_{2}$, on average, added only 0.001 to the $r^{2}$ of any multiple linear regression model.

\section{Discussion}

Reductions in $\mathrm{ScvO}_{2}$ occur when oxygen delivery to tissues is reduced and oxygen extraction is increased [8]. Lactate, the product of anaerobic metabolism, is considered the biomarker of choice for determining the presence of tissue hypoxia $[1-3,5,9]$. Recent critical care literature, including clinical practice guidelines, intertwines these two biomarkers as indicative of "tissue hypoperfusion," an entity which is not clearly defined, but which represents some combination of reduced tissue oxygen delivery and tissue hypoxia [30, 31]. Since lactate and $\mathrm{ScvO}_{2}$ are both well-studied independent predictors

Table 2 Selected multiple linear regressions predicting lactate

\begin{tabular}{llll}
\hline Variable removed from full model & $n$ & $r^{2}$ & $p$ value \\
\hline Full model $^{\mathrm{a}}$ & 319 & 0.3667 & $<0.001$ \\
Epinephrine & 327 & 0.3325 & $<0.001$ \\
Norepinephrine & 327 & 0.3462 & $<0.001$ \\
Linezolid & 327 & 0.3486 & $<0.001$ \\
Total bilirubin & 351 & 0.3350 & $<0.001$ \\
ALT & 327 & 0.3547 & $<0.001$ \\
Creatinine & 351 & 0.3503 & $<0.001$ \\
Cortisol & 885 & 0.2310 & $<0.001$ \\
SCVO & 327 & 0.3544 & $<0.001$ \\
AST & 347 & 0.2286 & $<0.001$ \\
\hline aFUll
\end{tabular}

aFull model: AST, ALT, $\mathrm{ScVO}_{2}$, cortisol, creatinine, total bilirubin, medications (epinephrine, norepinephrine, linezolid) of mortality in sepsis [17-23], their relationship should be clarified, because of their frequent use as interchangeable markers of improving tissue oxygenation [30, 31]. Furthermore, both lactate and $\mathrm{ScvO}_{2}$ are used as resuscitation markers in cardiogenic and hemorrhagic shock [24-28]. However, $\mathrm{ScvO}_{2}$ can be either increased or decreased in sepsis, while lactate has been considered an indicator of tissue oxygenation, due to its association with total oxygen debt $[15,16,22]$.

To our knowledge, this is the first direct analysis of the relationship between serum lactate levels and central venous oxygen saturation in critically ill patients, and the most comprehensive, although Weil evaluated the relationship of mixed venous oxygen saturation, oxygen delivery, and lactic acidosis [29]. Our data both complement and confirm those of Gattinoni et al., which demonstrate a complex relationship between lactate and $\mathrm{ScvO}_{2}$ [32]. In our single-center, retrospective, cohort study, lactate strongly predicted $\mathrm{ScvO}_{2}$ when patients were at or below the critical oxygen delivery threshold, but only $3 \%$ of shock patients met this criterion. In the overall population of critically ill patients, serum lactate predicted $\mathrm{ScvO}_{2}$ poorly, even after controlling for patients with high adrenal activation, normoxia, or kidney and liver dysfunction, all of which could modulate lactate levels via alternative mechanisms. Furthermore, when the analysis was limited to patients with increased lactate, or to patients with low $\mathrm{ScvO}_{2}$, there was no meaningful relationship between the two variables.

To evaluate the relationship of lactate and $\mathrm{ScvO}_{2}$ under conditions of potentially reduced oxygen delivery, we performed simple linear regression correlations of 
lactate and $\mathrm{ScvO}_{2}$ under conditions of presumed tissue hypoxia (lactate $>2 \mathrm{mmol} / \mathrm{L}$ ), high oxygen extraction $\left(\mathrm{ScvO}_{2} \leq 65 \%\right)$, anemia (hemoglobin $<7.0 \mathrm{~g} / \mathrm{dL}$ ), septic shock, and cardiogenic shock. Weak correlations between the two variables were observed with all of these conditions, suggesting the presence of other factors or combinations of factors that contributed to increased lactate. While the odds of having a decreased $\mathrm{ScvO}_{2}(<65 \%)$ were 1.69 times greater if lactate was increased $(>2 \mathrm{mmol} / \mathrm{L})$, only $31.1 \%$ of patients with an increased lactate had a decreased $\mathrm{ScvO}_{2}$. These numbers offer little support for using lactate and $\mathrm{ScvO}_{2}$ as interchangeable markers of "tissue perfusion." Recognizing that lactate and $\mathrm{ScrO}_{2}$ values can change rapidly, we evaluated simultaneous lactate and $\mathrm{ScrO}_{2}$ measurements, but the correlation remained weak. A previous study indirectly observed similar relationships, as $79 \%$ of septic patients without lactate clearance had simultaneous $\mathrm{ScvO}_{2}>70 \%$ [17]. Furthermore, low $\mathrm{ScvO}_{2}$ values can be observed in the presence of either high or low lactate levels [18]. Our serial measurements of simultaneous lactate and $\mathrm{ScvO}_{2}$ also support that the relationship of lactate and $\mathrm{ScvO}_{2}$ is inconsistent even within individual patients, further implicating the influence of factors other than tissue hypoxia on lactate levels.

One factor that may have led to the weak correlation between lactate and $\mathrm{ScrO}_{2}$ is the release of endogenous epinephrine during stress, leading to lactate production through beta-adrenergic receptor stimulation [33, 34]. We used serum cortisol as a surrogate marker for epinephrine, since epinephrine levels are not routinely measured in critically ill patients. Stress responses during critical illness stimulate the adrenal cortex to release cortisol and catecholamines, which correlate with the degree of stress experienced [35]. Although cortisol did not correlate strongly with serum lactate levels, it was a more consistent predictor of lactate than were tissue oxygenation markers.

Hepatic and renal dysfunction, common complications of shock and sepsis, can also reduce lactate elimination, potentially further contributing to the lack of correlation between lactate and the assessed markers. Lactate is metabolized by the liver and excreted by the kidney, so dysfunction of either organ could reduce lactate elimination [36, 37]. Our study showed that patients with liver dysfunction, but not kidney dysfunction, have significantly increased lactate levels. However, in the linear regressions, we observed only weak correlations between lactate and markers of hepatic or renal dysfunction. Our findings corroborate a previous study correlating lactate clearance with total bilirubin or renal creatinine clearance, which also did not demonstrate a significant relationship [38].

To mitigate the effect of alternate sources of lactate in critical illness on the relationship between lactate and
$\mathrm{ScvO}_{2}$, we performed regressions under multiple constraints. However, lactate and $\mathrm{ScvO}_{2}$ were weakly correlated under conditions of low adrenal activation, absence of acute or chronic hepatic and renal dysfunction, or absence of lactic acidosis-associated medications. Additionally, the multiple linear regression model does not fully explain the association of these variables, evidenced by low $r^{2}$ values, suggesting that additional factors outside the scope of our investigations affected serum lactate levels. AST contributed the largest increase to the $r^{2}$, suggesting that acute liver injury was the factor with the greatest predictive value for serum lactate.

It has been proposed that the inverse relationship of lactate and $\mathrm{ScrO}_{2}$ exists only below the critical oxygen delivery threshold (oxygen extraction ratio $\geq 50 \%$ ) $[8,39]$. However, only six of a possible 211 patients in our study exhibited an $\mathrm{O}_{2}$ extraction ratio of this magnitude. While a simple linear regression of lactate and $\mathrm{ScrO}_{2}$ in those patients displayed a strong correlation, it seems clear that relatively few shock patients may actually be at or below the critical threshold, suggesting that in the vast majority of patients, lactate and $\mathrm{ScvO}_{2}$ will neither accurately reflect one another, nor will lactate adequately reflect tissue hypoxia. Lactate and $\mathrm{ScvO}_{2}$ may be inversely correlated under certain conditions, but these conditions are unlikely to be present in most shock patients.

The predominantly weak correlation between lactate and $\mathrm{ScvO}_{2}$ demonstrates the complexity of lactate as a biomarker above the critical oxygen delivery threshold. Lactate consumption by the brain and heart is increased during stress, and lactate is released by the lungs during sepsis, which support that oxygen delivery is not the only factor, and perhaps not the major one, influencing serum lactate levels [40]. Increased lactate in critical illness is likely to be caused by a combination of factors, and the extent and timing of them may vary significantly from patient to patient. Additionally, even though lactate tends to increase at advanced stages of illness, $\mathrm{ScvO}_{2}$ can either increase or decrease, further complicating the relationship of lactate and markers of tissue hypoxia [23]. These factors most likely contributed to the weak correlations between lactate and the variables included in this study. However, our study does support that lactate and $\mathrm{ScrO}_{2}$ are correlated in the small subset of patients who have passed the critical oxygen delivery threshold. Therefore, in the vast majority of critically ill patients, lactate is primarily affected by factors other than tissue hypoxia and should not be used as a predictor of $\mathrm{ScvO}_{2}$ or tissue oxygenation.

Our study has some weaknesses, including that the findings are limited to a single center, the analysis is retrospective, and some aspects of the data are confirmatory of previous observations. Reduced thiamine levels can also be associated with increased lactate, but we 
were unable to account for thiamine levels, as these are rarely measured in our ICUs. While only $30 \%$ of the patient population had a shock diagnosis based on the ICD codes, this is likely due to well-reported discrepancies between administrative data and correct diagnoses [41]. In our institution, combined lactate and $\mathrm{ScvO}_{2}$ measurements are made only in patients with shock. We also combined $\mathrm{ScvO}_{2}$ and $\mathrm{SvO}_{2}$ measurements in the regressions, which could have altered the distribution of values. However, $\mathrm{SvO}_{2}$ should be strongly correlated with $\mathrm{ScvO}_{2}$, even if not equal to it, and lactate was also shown to have little correlation with the known $\mathrm{ScvO}_{2}$ and $\mathrm{SvO}_{2}$ values after March 2014. Lastly, we were not able to correlate lactate levels with endogenous epinephrine levels since epinephrine is not routinely measured. We used cortisol as a surrogate for epinephrine, but the relationship between cortisol and epinephrine levels is not fully understood and may not be consistent.

This study does have multiple strengths, including its large number of paired measurements and its evaluation of the intra-patient lactate/ $\mathrm{ScvO}_{2}$ relationships. We also evaluated multiple shock states, organ dysfunctions, and preexisting conditions, as well as conditions of presumed tissue hypoxia, low oxygen delivery, and increased oxygen extraction. Previous studies examining oxygen delivery have either assumed that increased lactate is equivalent to passing the critical $\mathrm{O}_{2}$ delivery point or have been achieved in patients being terminally removed from life support; neither of these circumstances is of clinical utility $[8,42]$. Our data suggest that very few shock patients (approximately $3 \%$ ) have reached critical levels of $\mathrm{O}_{2}$ delivery. Finally, we were able to test the within-patient direction and magnitude of change of lactate and $\mathrm{ScvO}_{2}$ values.

\section{Conclusions}

Based on the results of this single-center retrospective cohort study, lactate has very little predictive ability for $\mathrm{ScvO}_{2}$ in the vast majority of critically ill patients, even after accounting for factors that could interfere with such a relationship. In the clinical setting, lactate should not be used interchangeably with $\mathrm{ScvO}_{2}$ as a marker of tissue hypoxia.

\section{Additional files}

Additional file 1: Cross-tabulation table of lactate $>2 \mathrm{mmol} / \mathrm{L}$ and $\mathrm{ScvO}_{2}<65 \%$. Table displaying numbers of patients with increased or decreased lactate and concurrent increased or decreased $\mathrm{ScvO}_{2}$. (DOCX $12 \mathrm{~kb}$ )

Additional file 2: Selected Simple Linear Regression Data. Simple Linear Regressions involving serum lactate. (DOCX $14 \mathrm{~kb}$ )

Additional file 3: Lactate and $\mathrm{ScVO}_{2}$ Simple Linear Regression in patients with Oxygen Extraction Ratio $\geq 50 \%$. There were six patients who had both $\mathrm{SaO}_{2}$ and $\mathrm{ScvO}_{2}$ to allow the calculation of the Oxygen Extraction Ratio $\left(\left(\mathrm{SaO}_{2}-\mathrm{ScVO}_{2}\right) / \mathrm{SaO}_{2}\right)$. A lactate and $\mathrm{ScvO}_{2}$ simple linear regression in these patients produced an $r^{2}$ of $0.9303, p=0.0019$. The equation for the line of best fit was $\mathrm{ScvO}_{2}=-6.23$ (lactate) +59.2 . (TIF $347 \mathrm{~kb}$ )

Additional file 4: Restricted Cubic Spline Analysis of lactate and $\mathrm{ScvO}_{2}$ Three knots are inserted to describe the relationship of lactate and $\mathrm{ScvO}_{2}$. Only lactate levels $<10 \mathrm{mmol} / \mathrm{L}$ were used in this analysis. (TIF $1065 \mathrm{~kb}$ )

Additional file 5: Lactate vs $\mathrm{ScvO}_{2}$ sextiles. Lactate plotted vs $\mathrm{ScvO}_{2}$ sextiles. Data are presented as mean \pm standard error. (TIF $287 \mathrm{~kb}$ )

Additional file 6: Change in lactate vs Change in $\mathrm{ScvO}_{2}$ or $\mathrm{SvO}_{2}$ in patients with lactate clearance. Of the patients with multiple measurements of lactate and $\mathrm{ScvO}_{2}$ or $\mathrm{SvO}_{2}$ over the course of an ICU stay, there were 130 patients who had some level of lactate clearance (lactate difference $>0 \mathrm{mmol} / \mathrm{L}$ ). The $\mathrm{r}^{2}$ for the change in lactate vs change in $\mathrm{ScvO}_{2}$ or $\mathrm{SvO}_{2}$ regression for this population was $0.0137, p=0.19$. The equation for the line of best fit was $\mathrm{ScvO}_{2}$ or $\mathrm{SvO}_{2}$ difference $=-0.82$ (lactate difference) -0.66 . (TIF $415 \mathrm{~kb}$ )

Additional file 7: Lactate and Cortisol Simple Linear Regression. There were 603 measurements of lactate and cortisol in the appropriate time frame. $r^{2}=0.0627$ and the $p<0.001$. The equation for the line of best fit is Cortisol $=28.83+2.39$ (lactate). (TIF $504 \mathrm{~kb}$ )

Additional file 8: Lactate and ALT Simple Linear Regression. Only ALT values less than $100 \mathrm{U} / \mathrm{L}$ were included in the graph. There were 935 measurements of lactate and $\mathrm{ALT}(<100 \mathrm{U} / \mathrm{L})$ in the appropriate time frame. $r^{2}=0.011$ and the $p=0.0013$. The equation for the line of best fit is $\mathrm{ALT}=0.93$ (lactate) +27.0 . (TIF $1716 \mathrm{~kb})$

Additional file 9: Independent Samples T Tests for lactate in patients with CKD or CLD. Tables displaying independent samples t test summaries for lactate levels in patients with CKD or CLD. (DOCX $12 \mathrm{~kb}$ )

\section{Abbreviations}

ALT: Alanine aminotransferase; AST: Aspartate aminotransferase; CKD: Chronic kidney disease; CLD: Chronic liver disease; CRF: Chronic respiratory failure; EMR: Electronic medical record; ICD-10: International Classification of Diseases, Tenth Revision; ICD-9: International Classification of Diseases, Ninth Revision; ICUs: Intensive care units; LOS: Length of hospital stay; LOSICU: Length of ICU stay; NOS: Not otherwise specified; $\mathrm{ScvO}_{2}$ : Central venous oxygen saturation; $\mathrm{SvO}_{2}$ : Mixed venous oxygen saturation; TUKH: The University of Kansas Hospital in Kansas City, Kansas

\section{Acknowledgements}

Not applicable.

\section{Author's contributions}

SQS had full access to all of the data in the study and takes responsibility for the integrity of the data and the accuracy of the data analysis, including and especially any adverse effects. RB, DS, AP, LS, and WH contributed substantially to the study design, data analysis and interpretation, and the writing of the manuscript. All authors read and approved the final manuscript.

\section{Funding}

Roshan Bisarya was supported by a Parker B. Francis Foundation Undergraduate Research Fellowship.

\section{Availability of data and materials}

The datasets used and/or analyzed during the current study are available from the corresponding author on reasonable request.

\section{Ethics approval and consent to participate}

The protocol was approved by the University of Kansas Institutional Review Board, with approval number 00001581.

Consent for publication

Not applicable.

Competing interests

The authors declare that they have no competing interests. 


\section{Author details}

${ }^{1}$ School of Medicine, University of Kansas, Kansas City, KS, USA. ${ }^{2}$ Department of Internal Medicine, University of Kansas, Kansas City, KS, USA. ${ }^{3}$ Division of Pulmonary and Critical Care Medicine, University of Kansas, 3901 Rainbow Boulevard, Mail Stop 3047, Kansas City, KS 66160, USA. ${ }^{4}$ Department of Biostatistics, University of Kansas, Kansas City, KS, USA.

Received: 28 June 2019 Accepted: 27 August 2019

Published online: 05 September 2019

\section{References}

1. Bakker J. Lactate is THE target for early resuscitation in sepsis. Rev Bras Ter Intensiva. 2017;29:124-7.

2. Bakker J, Nijsten MW, Jansen TC. Clinical use of lactate monitoring in critically ill patients. Ann Intensive Care. 2013;3:12.

3. Fuller BM, Dellinger RP. Lactate as a hemodynamic marker in the critically ill. Curr Opin Crit Care. 2012;18:267-72

4. Jones AE. Point: should lactate clearance be substituted for central venous oxygen saturation as goals of early severe sepsis and septic shock therapy?Yes. Chest. 2011;140:1406-8.

5. Jones AE, Shapiro NI, Trzeciak S, Arnold RC, Claremont HA, Kline JA, et al. Lactate clearance vs central venous oxygen saturation as goals of early sepsis therapy: a randomized clinical trial. JAMA. 2010;303:739-46.

6. Ladakis C, Myrianthefs P, Karabinis A, Karatzas G, Dosios T, Fildissis G, et al. Central venous and mixed venous oxygen saturation in critically ill patients. Respiration. 2001;68:279-85.

7. Rivers EP, Elkin R, Cannon CM. Counterpoint: should lactate clearance be substituted for central venous oxygen saturation as goals of early severe sepsis and septic shock therapy?No. Chest. 2011;140:1408-13.

8. Walley KR. Use of central venous oxygen saturation to guide therapy. Am J Respir Crit Care Med. 2011;184:514-20.

9. Weil MH, Afifi AA. Experimental and clinical studies on lactate and pyruvate as indicators of the severity of acute circulatory failure (shock). Circulation. 1970;41:989-1001.

10. Rivers E, Nguyen B, Havstad S, Ressler J, Muzzin A, Knoblich B, et al. Early goal-directed therapy in the treatment of severe sepsis and septic shock. N Engl J Med. 2001;345:1368-77.

11. Reinhart K, Kuhn HJ, Hartog C, Bredle DL. Continuous central venous and pulmonary artery oxygen saturation monitoring in the critically ill. Intensive Care Med. 2004;30:1572-8.

12. Tahvanainen J, Meretoja O, Nikki P. Can central venous blood replace mixed venous blood samples? Crit Care Med. 1982;10:758-61.

13. Angus DC, Barnato AE, Bell D, Bellomo R, Chong CR, Coats TJ, et al. A systematic review and meta-analysis of early goal-directed therapy for septic shock: the ARISE, ProCESS and ProMISe investigators. Intensive Care Med. 2015:41:1549-60.

14. Vincent JL, De Backer D. From early goal-directed therapy to late(r) Scvo2 checks. Chest. 2018:154:1267-9.

15. Mizock BA, Falk JL. Lactic acidosis in critical illness. Crit Care Med. 1992;20:80-93.

16. Rashkin MC, Bosken C, Baughman RP. Oxygen delivery in critically ill patients. Relationship to blood lactate and survival. Chest. 1985;87:580-4

17. Arnold RC, Shapiro NI, Jones AE, Schorr C, Pope J, Casner E, et al. Multicenter study of early lactate clearance as a determinant of survival in patients with presumed sepsis. Shock. 2009;32:35-9.

18. Boulain T, Garot D, Vignon P, Lascarrou JB, Desachy A, Botoc V, et al. Prevalence of low central venous oxygen saturation in the first hours of intensive care unit admission and associated mortality in septic shock patients: a prospective multicentre study. Crit Care. 2014;18:609.

19. Filho RR, Rocha LL, Correa TD, Pessoa CM, Colombo G, Assuncao MS. Blood lactate levels cutoff and mortality prediction in sepsis-time for a reappraisal? A retrospective cohort study. Shock. 2016;46:480-5.

20. Marty P, Roquilly A, Vallee F, Luzi A, Ferre F, Fourcade O, et al. Lactate clearance for death prediction in severe sepsis or septic shock patients during the first 24 hours in intensive care unit: an observational study. Ann Intensive Care. 2013;3:3.

21. Mikkelsen ME, Miltiades AN, Gaieski DF, Goyal M, Fuchs BD, Shah CV, et al. Serum lactate is associated with mortality in severe sepsis independent of organ failure and shock. Crit Care Med. 2009;37:1670-7.

22. Pope JV, Jones AE, Gaieski DF, Arnold RC, Trzeciak S, Shapiro NI, et al. Multicenter study of central venous oxygen saturation (ScvO (2)) as a predictor of mortality in patients with sepsis. Ann Emerg Med. 2010;55:40-6 e1.
23. Textoris J, Fouche L, Wiramus S, Antonini F, Tho S, Martin C, et al. High central venous oxygen saturation in the latter stages of septic shock is associated with increased mortality. Crit Care. 2011;15:R176.

24. Dickstein K, Cohen-Solal A, Filippatos G, McMurray JJ, Ponikowski P, PooleWilson PA, et al. ESC guidelines for the diagnosis and treatment of acute and chronic heart failure 2008: the task force for the diagnosis and treatment of acute and chronic heart failure 2008 of the European Society of Cardiology. Developed in collaboration with the Heart Failure Association of the ESC (HFA) and endorsed by the European Society of Intensive Care Medicine (ESICM). Eur Heart J. 2008;29:2388-442.

25. Gallet R, Lellouche N, Mitchell-Heggs L, Bouhemad B, Bensaid A, DuboisRande $J$, et al. Prognosis value of central venous oxygen saturation in acute decompensated heart failure. Arch Cardiovasc Dis. 2012;105:5-12.

26. Gutierrez G, Reines HD, Wulf-Gutierrez ME. Clinical review: hemorrhagic shock. Crit Care. 2004:8:373-81.

27. Lazzeri C, Valente S, Chiostri M, Gensini GF. Clinical significance of lactate in acute cardiac patients. World J Cardiol. 2015;7:483-9.

28. Nemeth M, Tanczos K, Demeter G, Erces D, Kaszaki J, Mikor A, et al. Central venous oxygen saturation and carbon dioxide gap as resuscitation targets in a hemorrhagic shock. Acta Anaesthesiol Scand. 2014;58:611-9.

29. Astiz ME, Rackow EC, Kaufman B, Falk JL, Weil MH. Relationship of oxygen delivery and mixed venous oxygenation to lactic acidosis in patients with sepsis and acute myocardial infarction. Crit Care Med. 1988;16:655-8.

30. Dellinger RP, Levy MM, Rhodes A, Annane D, Gerlach H, Opal SM, et al. Surviving Sepsis campaign: international guidelines for management of severe sepsis and septic shock, 2012. Intensive Care Med. 2013;39:165-228.

31. Rhodes A, Evans LE, Alhazzani W, Levy MM, Antonelli M, Ferrer R, et al. Surviving Sepsis Campaign: International Guidelines for Management of Sepsis and Septic Shock: 2016. Intensive Care Med. 2017;43:304-77.

32. Gattinoni L, Vasques F, Camporota L, Meessen J, Romitti F, Pasticci I, et al. Understanding lactatemia in human sepsis: potential impact for early management. Am J Respir Crit Care Med. 2019. https://doi.org/10.1164/ rccm.201812-23420C.

33. Clausen T. Na+-K+ pump regulation and skeletal muscle contractility. Physiol Rev. 2003;83:1269-324

34. Suetrong B, Walley KR. Lactic acidosis in sepsis: it's not all anaerobic: implications for diagnosis and management. Chest. 2016:149:252-61.

35. Marik PE, Bellomo R. Stress hyperglycemia: an essential survival response! Crit Care. 2013:17:305

36. Bellomo R. Bench-to-bedside review: lactate and the kidney. Crit Care. 2002:6:322-6

37. Phypers B, Pierce JM. Lactate physiology in health and disease. Contin Educ Anaesth Crit Care Pain. 2006;6:128-32.

38. Levraut J, Ciebiera JP, Chave S, Rabary O, Jambou P, Carles M, et al. Mild hyperlactatemia in stable septic patients is due to impaired lactate clearance rather than overproduction. Am J Respir Crit Care Med. 1998:157:1021-6.

39. Schumacker PT, Rowland J, Saltz S, Nelson DP, Wood LD. Effects of hyperthermia and hypothermia on oxygen extraction by tissues during hypovolemia. J Appl Physiol. 1987;63:1246-52.

40. Garcia-Alvarez M, Marik P, Bellomo R. Sepsis-associated hyperlactatemia. Crit Care. 2014;18:503.

41. O'Malley KJ, Cook KF, Price MD, Wildes KR, Hurdle JF, Ashton CM. Measuring diagnoses: ICD code accuracy. Health Serv Res. 2005;40:1620-39.

42. Ronco JJ, Fenwick JC, Tweeddale MG, Wiggs BR, Phang PT, et al. Identification of the critical oxygen delivery for anaerobic metabolism in critically III septic and nonseptic humans. JAMA. 1993;14:1724-30.

\section{Publisher's Note}

Springer Nature remains neutral with regard to jurisdictional claims in published maps and institutional affiliations. 